\title{
PENGGUNAAN KITOSAN SEBAGAI BIOMATERIAL DI KEDOKTERAN GIGI
}

\author{
(USE OF CHITOSAN AS A BIOMATERIAL IN DENTISTRY)
}

\author{
Ika Devi Adiana, Lasminda Syafiar \\ Departemen Ilmu Material dan Teknologi Kedokteran Gigi \\ Fakultas Kedokteran Gigi, Universitas Sumatera Utara \\ Jl. Alumni No.2, Kampus USU Medan 20155
}

\begin{abstract}
The use of natural products in medicine is growing explain rapidly. One of the natural products is chitosan. The purpose of this paper is to explain the use of chitosan in dentistry. Chitosan (poly- $\beta-1,4-$ Glucosamine) is a natural biopolymer in nature that has a linear chain with structural formula $\left(\mathrm{C}_{6} \mathrm{H}_{11} \mathrm{NO}_{4}\right) \mathrm{n}$ that can be obtained from the distillation process of chitin. Chitin is found in many animals, especially sea crustaceans, such as: blankas, crab, clam, shrimp, rajungan, squid, insect and fungi. Chitosan has several favorable properties such as biocompatible, biodegradable, non toxic, and mucoadhesion, therefore chitosan is often used in biomedical applications. In conclusion, Chitosan can be used as an antibacterial, to inhibit/kill microorganisms, to decrease pain, and to improve the properties of dental materials.
\end{abstract}

Key words: chitosan, biomaterial, antibacterial

\begin{abstract}
Abstrak
Pengunaan produk-produk alam di bidang kedokteran saat ini semakin berkembang pesat. Salah satu bahan alami yang digunakan adalah kitosan. Tujuan penulisan ini adalah untuk menjelaskan kegunaan kitosan di bidang kedokteran gigi. Kitosan (poly- $\beta$-1,4-glukosamine) merupakan makalah biopolymer alami di alam yang memiliki rantai linear dengan rumus struktur $\left(\mathrm{C}_{6} \mathrm{H}_{11} \mathrm{NO}_{4}\right)$ n yang dapat diperoleh dari proses destilasi kitin. Kitin ditemukan banyak pada hewan laut berkulit keras seperti blankas, kepiting, kerang, udang, rajungan, cumi-cumi, jenis serangga dan jamur. Kitosan memiliki beberapa sifat yang menguntungkan seperti biokompatibel, biodegradable, tidak beracun serta mucoadhesion sehingga kitosan sering digunakan pada pengaplikasian biomedis. Sebagai kesimpulan, kitosan dapat digunakan sebagai anti bakteri, menghambat/ membunuh mikroorganisme, menurunkan rasa nyeri, serta memperbaiki sifat-sifat material di bidang kedokteran gigi.
\end{abstract}

Kata kunci: kitosan, biomaterial, antibacterial

\section{PENDAHULUAN}

Saat ini penggunaan produk-produk alam di bidang kedokteran gigi semakin berkembang pesat. Kitosan merupakan salah satu biomaterial yang akhir-akhir ini terus dikembangkan karena memiliki berbagai manfaat medis dan telah terbukti aman untuk manusia. Kitosan memiliki beberapa sifat istimewa, antara lain biokompatibilit baik, biodegradable, mucoadhesion, tidak bersifat toksik, tidak menyebabkan reaksi immunologi, dan tidak menyebabkan kanker sehingga kitosan sering digunakan pada pengaplikasian biomedis. ${ }^{1}$

Kitosan pertama kali ditemukan oleh Rouget pada tahun 1985. Kitosan merupakan derivat kitin dengan adanya $\mathrm{N}$-deasitilasi yang merupakan biopolimer alami. ${ }^{1,2}$ Kitin berasal dari eksoskeleton krustasea (kepiting, udang dan kerang-kerangan). Persediaan limbah laut yang cukup besar di Indonesia menjadikan limbah laut sebagai sumber kitin, sangat berpotensi menjadikan kitosan mudah diperoleh di alam. ${ }^{3}$ Kegunaan kitosan sebagai bahan yang multiguna tidak terlepas dari sifat alaminya, terutama sifat kimia kitosan yaitu polimer poliamin yang berbentuk linear, mempunyai gugus amino dan hidroksil yang aktif. ${ }^{4}$ Kitosan memiliki kualitas kimia dan biologi yang sangat baik sehingga dapat digunakan secara luas dibidang industri maupun dibidang kesehatan. ${ }^{1}$

Berdasarkan adanya pernyataan tentang beberapa 
sifat istimewa kitosan, maka kitosan dan modifikasinya dengan bahan lain dapat digunakan untuk aplikasi klinis sebagai biomaterial. ${ }^{4}$ Kombinasi penggunaan klorheksidin dengan kitosan molekul rendah dapat dimanfaatkan sebagai anti plak, kombinasi ini dapat memperbaiki bakterial klorheksidin dalam membunuh Streptokokus. ${ }^{5}$ Palma-Dibb meneliti efek kitosan pada konsenterasi dan larutan yang berbeda terhadap permukaan dentin, dan hasilnya larutan kitosan dalam asam hidroklorik menghasilkan permukaan dentin tanpa smear layer dan terdapat collagen fiber. ${ }^{6}$ Tujuan penulisan makalah ini adalah untuk menjelaskan penggunaan kitosan di bidang kedokteran gigi.

\section{PENGERTIAN DAN KOMPOSISI KITOSAN}

Kitosan (poly- $\beta$-1,4-glukosamine) merupakan biopolimer alami di alam setelah selulosa yang memiliki rantai linear dengan rumus struktur $\left(\mathrm{C}_{6} \mathrm{H}_{11} \mathrm{NO}_{4}\right) \mathrm{n}$ dan merupakan hasil $\mathrm{N}$-diasetilisasi dari kitin (Gambar 1). Kitin banyak terkandung pada hewan laut yang berkulit keras seperti: blankas, kepiting, kerang, udang, rajungan, cumi-cumi, jenis serangga dan jamur. ${ }^{1}$

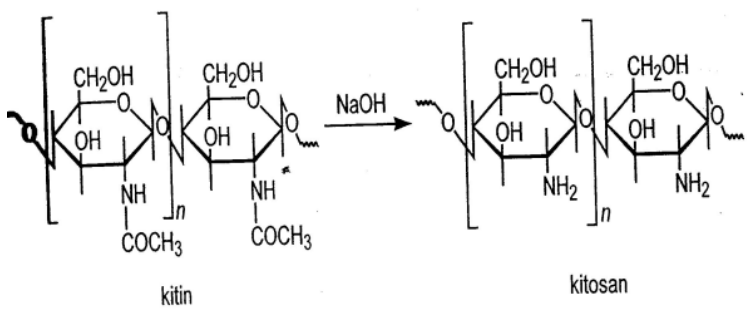

Gambar 1. Reaksi pembentukan kitosan dari kitin ${ }^{1}$

Komposisi kitosan terdiri atas karbon, hidrogen, dan nitrogen serta dapat larut dalam pelarut asam seperti asam asetat, asam formiat, asam laktat, asam sitrat dan asam hidroklorat. ${ }^{1}$ Kitosan tidak larut dalam air, alkali dan asam mineral encer kecuali dibawah kondisi tertentu yaitu dengan adanya sejumlah pelarut asam sehingga dapat larut dalam air, methanol, aseton dan campuran lainnya. Kelarutan kitosan dipengaruhi oleh bobot molekul dan derajat deasetilasi. ${ }^{1}$ komposisi kimia kitosan adalah 40,30\% karbon; 5,83\% hidrogen dan 6,35\% nitrogen. ${ }^{1}$

Berdasarkan viskositasnya, berat molekul kitosan terdiri atas tiga yaitu kitosan bermolekul rendah, kitosan bermolekul sedang dan kitosan bermolekul tinggi. Kitosan bermolekul rendah berat molekulnya dibawah $400.000 \mathrm{Mv}$ dan kitosan bermolekul sedang berat molekulnya berkisar 400.000-800.000 $\mathrm{Mv}$, didapat dari hewan laut seperti cangkang atau yang berkulit lunak misalnya udang, cumi-cumi dan rajungan. Kitosan bermolekul tinggi berat molekulnya berkisar $800.000-1.100 .000 \mathrm{Mv}$ biasanya didapat dari hewan laut bercangkang keras seperti kepiting, kerang dan blangkas (Gambar 2). ${ }^{1,4}$

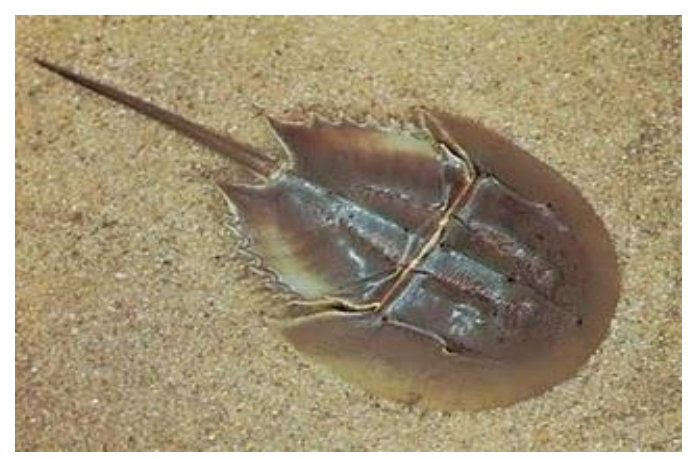

Gambar 2. Kitosan Blangkas ${ }^{4}$

\section{PENGGUNAAN KITOSAN DI BIDANG KEDOKTERAN GIGI}

Multiguna kitosan tidak terlepas dari sifat alaminya, terutama sifat kimianya yaitu polimer poliamin berbentuk linear dan mempunyai gugus amino dan hidroksil yang aktif. ${ }^{1,4}$ Kitosan banyak digunakan di bidang industri dan bidang kesehatan karena memiliki kualitas kimia dan biologi yang sangat baik ${ }^{1}$. Penggunaan kitosan di bidang kedokteran gigi sebagai biomaterial antara lain: antibakterial, dressing, penyembuh luka/ regenerasi tulang, memperbaiki sifat-sifat material kedokteran gigi

\section{Kitosan Sebagai Antibakterial}

Beberapa penelitian terbaru mengenai aktifitas antibakterial kitosan menyatakan bahwa kitosan sangat efektif dalam menghambat pertumbuhan bakteri. Kitosan telah menunjukkan aktivitas antimikroba yang tinggi terhadap berbagai patogen pembusuk dan mikroorganisme, termasuk jamur, bakteri gram positif dan gram negatif. Kitosan sebagai antimikroba dipengaruhi oleh faktor-faktor intrinsik seperti jenis kitosan, derajat polimerisasi kitosan sedangkan faktor-faktor ekstrinsik seperti organisme mikroba, kondisi lingkungan dan adanya komponen lainnya. ${ }^{7}$

Menurut Chen, antibakteri kitosan lebih efektif terhadap bakteri gram negatif daripada bakteri gram positif dan kitosan berpotensi sebagai desinfektan alami. Penelitian Chung., juga menyatakan bahwa penyerapan kitosan oleh bakteri gram negatif lebih besar daripada bakteri gram positif dimana aktivitas antimikroba dapat meningkat sejalan dengan meningkatnya derajat deasetilisasi. ${ }^{8}$

Menurut Shi etal. penggabungan nanopartikel 
dari kitosan dan quaternary ammonium kitosan derivatif dalam bone cements dapat memberikan tindakan antibakteri yang efektif terhadap S. Aureus dan S. Epidermidis secara in vitro. ${ }^{9}$

\section{Kitosa Sebagai Bahan Dressing Saluran Akar}

Saat ini penggunaan bahan dressing semakin berkembang. Penggunaan bahan dressing yang aman, dan dapat diterima oleh jaringan tanpa menimbulkan efek samping seperti bahan non-biologi yang biasa digunakan saat ini sebagai bahan dressing diantaranya kalsium hidroksida $\left(\mathrm{Ca}(\mathrm{OH})_{2}\right)$, zinc oxide cement, fosfat dan cyanoacrylate. Walaupun bahanbahan ini memiliki kebaikan seperti kemampuan antibakterial yang baik, namun bahan-bahan ini juga memiliki efek samping bagi jaringan tubuh yang harus dipertimbangkan. ${ }^{4}$ Oleh karena itu, dikembangkan suatu bahan dressing yang bersifat alami, biokompatibel, biodegradable dan memiliki efek antibakteri yaitu kitosan. ${ }^{10}$

Menurut Suzuki et al. larutan kitosan menunjukkan kemanjuran sebagai antibakteri dan mengangkat smear layer yang berguna untuk irigasi saluran akar. ${ }^{11}$ Pimenta et al. menyatakan bahwa $0,2 \%$ kitosan, $15 \%$ EDTA dan asam sitrat 10\% menunjukkan efek yang sama dalam mengurangi microhardness dentin. ${ }^{12}$

Silva et al. menyatakan bahwa $0,2 \%$ kitosan dapat dipakai sebagai bahan irigasi saluran akar dan efektif mengangkat smear layer dari tengah dan $1 / 3$ apikal saluran akar dan 0,2\% kitosan memiliki efek terbesar pada demineralisasi akar dentin. ${ }^{13}$ Penelitian Elsaka dan Elnaghy menyatakan bahwa $\mathrm{Ca}(\mathrm{OH})_{2}$ yang dikombinasikan dengan kitosan adalah obat intrakanal yang menjanjikan dan efektif dalam terapi endodontik. ${ }^{14}$

\section{Kitosan Sebagai Bahan Penyambuh luka/ regenerasi tulang}

Dalam bidang medis, membran kitosan digunakan sebagai asuhan luka. Membran kitosan sengaja dibuat berpori seperti spons untuk mempermudah sirkulasi udara dan mencegah akumulasi air pada luka, sehingga luka menjadi kering dan cepat sembuh. ${ }^{1}$

Azad et al. menyatakan bahwa membran jala kitosan menunjukkan efek positif pada re-epitelisasi dan regenerasi lapisan granular. Membran jala kitosan adalah pengganti potensial untuk pembalut luka manusia. Howling et al. juga mengatakan bahwa kitosan dapat bermanfaat dalam penyembuhan luka karena memberi efek terhadap proliferasi sel fibroblast kulit manusia dan sel keratinosit secara in vitro.
Dibidang kedokteran gigi pemakaian kitosan juga telah diteliti oleh beberapa peneliti diantaranya oleh Park YJ et al. menyatakan bahwa spons kitosan dan PDGF-BB-loaded chitosan sponge bermanfaat untuk meningkatkan regenerasi tulang periodontal. Bumgardner et al. menyatakan bahwa kitosan memiliki potensi yang biokompatibel, terhadap lapisan bioaktif perangkat implan ortopedi dan kraniofasial.

\section{Kitosan Sebagai Bahan Memperbaiki Sifat-Sifat Material Kedokteran Gigi}

Selain penggunaan diatas, kitosan juga dapat memperbaiki sifat material di bidang kedokteran gigi dengan cara memodifikasi atau menambahkan kitosan dengan material kedokteran gigi lainnya. Diantaranya dengan penambahan gel kitosan pada alginat dapat memperbaiki struktur ikatan silang, akibatnya ikatan silang gel menjadi lebih kaku dan gel menjadi lebih kuat. Semakin tinggi nilai kekuatan pecah gel, maka ikatan yang terjadi antara polimer-polimer yang membentuk jaringan gel tersebut semakin kaku dan semakin kuat. ${ }^{1}$

Petri et al. menyatakan bahwa semen ionomer kaca yang dimodifikasi dengan kitosan bermolekul rendah menunjukkan penambahan $0,0044 \%$ berat kitosan, dapat meningkatkan sifat mekanik seperti flexural strength dan meningkatkan pelepasan ion fluor. ${ }^{16}$ Lee et al. menyatakan bahwa sel-adhesi dan sifat mekanik membran komposit meningkat dengan meningkatnya konsentrasi kitosan yang terdistribusi secara merata dalam membran komposit. Konsentrasi kitosan tidak memiliki efek negatif pada morfologi sel, viabilitas, dan proliferasi serta memiliki biokompatibilitas yang baik. Konsentrasi kitosan pada membran komposit adalah masa yang baik untuk membran regenerasi tulang dalam aplikasi masa depan ${ }^{17}$.

\section{PEMBAHASAN}

Kitosan adalah poli-(2-amino-2-deoksi- $\beta$-(1-4)-Dglukopiranosa) dengan rumus molekul $\left(\mathrm{C}_{6} \mathrm{H}_{11} \mathrm{NO}_{4}\right)_{\mathrm{n}}$ dapat diperoleh dari deasetilasi kitin. Proses deasetilasi kitosan dapat dilakukan dengan cara kimiawi maupun enzimatik. Proses secara kimia menghasilkan kitosan dengan bobot molekul yang beragam dan deasetilasi yang acak sehingga sifat fisik dan kimia kitosan tidak seragam. Selain itu proses kimia juga dapat menimbulkan pencemaran lingkungan, sulit dikendalikan, dan melibatkan banyak efek samping. Oleh karena itu proses enzimatik digunakan untuk menutupi kekurangan proses kimia karena pada dasarnya deasetilasi secara enzimatik bersifat selektif dan tidak merusak struktur rantai kito- 
san, sehingga menghasilkan kitosan dengan karakteristiki yang lebih seragam agar dapat memperluas bidang aplikasinya. ${ }^{1}$

Pengaplikasian kitosan diberbagai bidang terutama di kedokteran gigi tidak terlepas dari sifatnya alaminya yang multiguna. Banyak penelitian yang telah dilakukan untuk mengetahui dan membuktikan kegunaan kitosan sebagai bahan biomaterial alami, baik secara tunggal maupun jika digabungkan atau dimodifikasi dengan material lain di bidang kedokteran gigi. ${ }^{1}$ Stamford et al. menyatakan bahwa kitosan merupakan agen antikariogenik dan aplikasi kitosan sebagai biomaterial kedokteran gigi untuk pencegahan dan terapi karies gigi dimana penggunaan kitosan dalam formulasi yang berbeda, seperti pasta gigi, obat kumur dan permen telah berperan sebagai antibakteri untuk bakteri yang termasuk kelompok Streptokokus, menghambat pertumbuhan bakteri kariogenik dan proses demineralisasi enamel gigi secara in vitro, dan merangsang saliva secara in vivo. ${ }^{18}$ Ezoddini-Ardakani $\mathrm{F}$ et al. mengatakan bahwa kitosan telah terbukti menjadi salah satu biomaterial yang paling baik untuk aplikasi ortopedi dan gigi. Kitosan dianggap sebagai alternatif yang cocok untuk cangkok tulang. Kitosan meningkatkan regenerasi tulang pada kehilangan tulang gigi. ${ }^{19}$

Sebagai kesimpulan, kitosan merupakan biomaterial alami yang aman dan dapat digunakan dalam berbagai bidang di kedokteran gigi antara lain sebagai anti bakterial, menghambat/ membunuh mikroorganisme, penyembuhan luka/ menurunkan rasa nyeri, serta memperbaiki sifat-sifat material di kedokteran gigi seperti meningkatkan compressive dan flexural strength material kedokteran gigi.

\section{Referensi}

1. Sugita P, Wukirsari T, Sjahriza A, Wahyono D. Kitosan: sumber biomaterial dimasa depan. IPB press. Kampus IPB Taman Kencana Bogor. 2009: 3, 19-20, 54-55, 148.

2. Tika I, Abidin T. Efek kitosan belangkas bermolekul tinggi dengan pelarut gliserin sebagai alternative bahan dressing saluran akar terhadap Candida albicans. dentika Dent J. 2010 : (15) ; 71-3.

3. Harjito L. Chitosan sebagai bahan pengawet pengganti formalin. Majalah pangan: Media komunikasi dan informasi 2006: 46.

4. Abidin A, Agusnar H, Farahany W. Efek dentinogenesis kitosan dan derivatnya terhadap inflamasi jaringan pulpa gigi reversible. Laporan akhir penelitian riset pembinaan IPTEK kedokteran 2006/ 2007. Medan. Fakultas Kedokteran Gigi USU. 2006: 16-8.
5. Decker EM, Von Ohle R, Wiech I. A synergistic chlorhexidine chitosan combination for improved antiplaque strategies. J Periodontal Res. 2005; 40: 373-7.

6. Palma-Dibb RG. Chitosan effect on dentin surface: SEM analysis. Int Endo J. 2012.

7. Hafdani FN, Sadeghinia N. A Review on Appication of chitosan as a Natural Antimicrobial. World Academy of Science, Engineering and Technology. 2011: 74; 257-4.

8. Chun YC, Relationship beween antibacterial activity of chitosa and surface characteristics of cell wall. Acta Pharmacol Sin. 2004: 25 (7); 932-6.

9. Shia Z, Neoha KG, Kanga ET, Wang W. Antibacterial and mechanical properties of bone cement impregnated with chitosan nanoparticles. J Biomaterials 27: 2006; 2440-9.

10. Banurea FE, Abidin T. Antibacterial effect of high molecul chitosan blankas (limulus polyphemus) against fusobacterium nucleatum. arch orofasial sc Kelantan, Malaysia. 2008: 3(2): 73.

11. Suzuki S, Yamada Y, Masuda Y, Morisaki H, Kuwata H, Miyazaki T. The evaluation of Chitosan solution for root canal treatment. https://iadr.confex. com/iadr/apr13/webprogram/Paper181080.html (5 Januari 2014).

12. Pimenta JA, Zaparolli D, Pécora JD, Cruz-Filho AM. Chitosan: effect of a new chelating agent on the microhardness of root dentin. Brazilian Dent J. 2012: 23(3).

13. Silva PV, Guedes DF, Nakadi FV, Pécora JD, CruzFilho AM. Chitosan: a new solution for removal of smear layer after root canal instrumentation. Int Endod J 2013: 46(4); 332-8.

14. Elsaka SE, Elnaghy AM. Antibacterial activity of calcium hydroxide combined with chitosan solutions and the outcomes on the bond strength of real seal sealer to radicular dentin. J Biomedical Res 2012: 26: 1-7.

15. Azad AK, Sermsintham N, Chandrkrachang S, Stevens WF. Chitosan membrane as a woundhealing dressing: characterization and clinical application. J Biomed Mater Res B Appl Biomaterial 2004 15; 69(2): 216-22.

16. Petri DFS, Donega J, Benassi AM. Preliminary study on chitosan modified glass ionomer restoratives. J Dent Materials 2007; 23: 1004-10.

17. Lee SB, Kwon JS, Lee YK, Kim KM, Kim KN. Bioactivity and mechanical properties of collagen composite membranes reinforced by chitosan and $\beta$ tricalcium phosphate. J Biomedical Materials Res B Appl Biomaterial. 2012: 100B(7); 1935-42.

18. Stamford TCM, Stamford-Arnaud TM, de Medeiros HMC, Macedo RO, de Campos-Takaki GM. Microbiological chitosan: potential application as anticariogenic agent. 2012; 229-15.

19. Ezoddini-Ardakani F, Azam AN, Yassaei S, Fatehi F, Rouhi G. Effects of chitosan on dental bone repair. Science Res. 2011: 3(4); 200-5. 